\section{Doing what comes naturally}

Richard Mabey

Man and the Natural World: Changing

Attitudes in England 1500-1800.

By Keith Thomas.

Allen Lane/Pantheon: 1983. Pp.425. £14.95, \$19.95.

IN THE preface to this expanded version of his 1979 Trevelyan Lectures, Keith Thomas thanks his audience for enduring "conditions so wintry as to remind all present that man's conquest of the natural world is still far from complete"'. Oldfashioned awe is an uncommon commodity these days, and Thomas does not find much evidence of it in this survey of three centuries of our relationships with the natural world. Subjugation may have given way to stewardship, but man has remained firmly in the saddle.

Thomas's argument, exhaustively documented (there are, at a rough count 4,000 references) and elegantly composed, is nonetheless very simple. 'n the "early modern period" a series of contiguous intellectual revolutions began to undermine our belief that the rest of the natural world had been created solely for our own use and spiritual enlightenment. The cracks in this Christian anthropocentrism widened with the birth of an apparently more objective natural philosophy in the eighteenth century (pioneered ironically by a new breed of rationalist clergy), which viewed the natural world as having an existence in its own right, and led inevitably to the love affairs with nature of ninteenthcentury Romantics and twentieth-century conservationists.

At the time these new perceptions were deeply unsettling. They weakened the boundary which separated us from the rest of creation, and which was used to define and justify our actions. And their aftershocks help to explain the perplexity we still feel in trying to evolve a code of ecological ethics for a species which is simultaneously natural and self-consciously cultural. But some shifts in sensibility were undoubtedly permanent. We are now sufficiently acquainted with the beastly nature of our own bodies, for instance, to be able to laugh at earlier struggles to reconcile the idea of Divine Creation with the realities of defaecation. Thomas quotes one Stuart theologian: ". . . Yet I will be a more noble creature; and at the very time when my natural necessities debase me to the condition of the beast, my spirit shall (I say at that very time!) rise and soar . . .".

But I think Thomas misjudges how much this reflection represented widespread changes in social attitudes and how much the shifting moods of a particular, educated class. Although responsibility by privilege replaced subjugation by right, we went on behaving in much the same way. Even aboard spaceship Earth, some animals are more equal than others. How, for instance, do we categorize the scientific culling of species, justified as being done for the animals' (or the ecosystem's) “own good"? And though Thomas makes up an horrific catalogue of early cruelties, we have to face the facts of our own more subtle tortures. In country sporting enclaves, heads are still bitten off live animals, and cock-fighting and badgerbaiting flourish. And out of sight in another sense we have added a whole new set of ordeals, from the factory farm to the aerial crop-spray, that might well turn the stomach of a country-born, seventeenthcentury burner of cats.

These examples could be rightly challenged as anecdotal, and not the way to write history. Yet it must be said that Thomas's card-index approach to history, culling tales and evidence from diaries, cookery books, poems, is also, precisely, anecdotal; and that to group this evidence in accordance with its superficial resemblances (much as Victorian anthropologists used to "collect" and group types of human behaviour, regardless of context) produces a version of history where change appears to be arbitrary and subjective. On the matter of trees, for example, Thomas's argument requires a gradual increase in respect for trees and woodland. His carefully selected evidence (laments over felling, eulogies to the "spirits" of trees) obscures the statistical fact that the eighteenth century was a period of intense woodland clearance, only rivalled by the past 40 years. Again, the practice of lopping trees for firewood was not discontinued in the eighteenth century because, as Thomas suggests, it was seen as a "violation" of trees (it actually extended their lives) but because economic and political measures had led to the extinction of commoners' rights to wood in favour of the landowners' rights to timber.

The neglect of the idea that attitudes are determined as much by facts of ownership, working relationships and physical intimacy as by period or fashion is the major weakness of this book. 't is especially sad that we are given so little evidence about those whose relationships with nature were most intimate - the landworkers - for it is in their pre-rational view of the world, with its fears and folklore, its ecological magic and sense of natural affinities, that the green revival has its roots as much as in the "modern" understanding documented by Thomas. But they are eclectic roots, and perhaps this is the spirit in which to approach what is, for all its rather glib generalizations, a compulsive and fascinating book. It is a kind of bestiary of our historical views of nature, an anthology of our persistent, obsessive, inquisitive tinkerings with the Earth, a salutary reminder that we couldn't stop behaving like this without ceasing to be human, so we had better do it well.

Richard Mabey is a member of the Nature Conservancy Council and writer on countryside matters and landscape history.

\section{Beyond conception?}

\section{W.D. Billington}

Immunological Fertility Regulation.

By Warren R. Jones.

Blackwell Scientific/Blackwell Mosby:

1983. Pp.270. £29.50, \$41.95.

ECONOM:C and social factors continue to dictate the pressing need for a reduction in human population increase at the global level. Despite this, it is an uncomfortable fact that there is no totally acceptable and safe contraceptive procedure currently available for use either in Western societies or in developing countries. Moreover, and more disturbingly, there have been no innovatory advances in contraceptive technology in the past decade, but merely a modest tinkering with the efficacy or applicability of existing methods. There is presently even a disturbing degree of political inertia and industrial disinterest in this area.

Fortunately, there are still those who recognize the problems and have the ability and drive to seek out means of attacking them. One such person is Warren Jones, obstetrician, scientist and committee man, who has lost few opportunities to promote the idea of regulating human fertility by immunological manipulation. Although recent years have seen the publication of a number of reviews concerned with the
Landowners at home in the eighteenth-century landscape - detail from Gainsborough's painting of $\mathrm{Mr}$ and Mrs Robert Andrews, $c$.1750. (Courtesy of the National Gallery, London.) 